\title{
POLA SUHU PERMUKAAN DAN UDARA MENGGUNAKAN CITRA SATELIT LANDSAT MULTITEMPORAL
}

\author{
ESURFACE AND AIR TEMPERATURE PATTERN USING \\ MULTITEMPORAL SATELLITE IMAGE LANDSAT
}

\author{
Wiweka ${ }^{1}$ \\ (Diterima tanggal 30-11-2013; Disetujui tanggal 02-01-2014)
}

\begin{abstract}
ABSTRAK
Penelitian ini bertujuan untuk melihat perbandingan nilai dari suhu udara pada tahun 2000, 2003, dan 2013 serta membandingkan nilai dari radiasi netto, fluks bahang, dan suhu udara pada tahun 2000 dan 2003 pada wilayah path/ row 118/065 yaitu wilayah Jawa Timur bagian utara dan Pulau Madura. Metode yang digunakan untuk pengolahan data suhu permukaan adalah berdasarkan nilai radiance pada band 6 citra Landsat 7 ETM+ path/row 118/065 tahun 2000 dan 2003 serta nilai radiance pada band 10 dan band 11 citra Landsat 8 TIRS path/row 118/065 tahun 2013. Radiasi netto tahun 2000 dan 2003 menggunakan pengolahan radiance dan reflectance landsat 7 melalui pendekatan persamaan Stefan-Boltzman. Fluks bahang tanah menggunakan radiance yang diklasifikasikan berdasarkan nilai dari proporsi radiasi netto dan bahang tanah pada penelitian sebelumnya. Fluks bahang terasa menggunakan pendekatan bowen ratio, sedangkan fluks bahang laten menggunakan persamaan neraca energi. Nilai suhu udara pada tahun 2000 memiliki nilai yang tinggi berkisar antara $8^{\circ}$ hingga $60^{\circ} \mathrm{C}$, Sedangkan pada tahun 2003 berkisar antara $8^{\circ}$ hingga $45^{\circ} \mathrm{C}$ dan 2013 berkisar antara $12.8^{\circ}$ hingga $41.2^{\circ} \mathrm{C}$. Radiasi netto di wilayah kajian pada tahun 2000 berkisar antara 366 hingga $792 \mathrm{~W} / \mathrm{m} 2$. Sedangkan pada tahun 2003 berkisar antara 340 hingga $761 \mathrm{~W} / \mathrm{m} 2$. Nilai fluks bahang tanah tahun 2000 berkisar antara 25 hingga $82 \mathrm{~W} / \mathrm{m}^{2}$, sedangkan tahun 2003 nilai fluks bahang tanah berkisar antara 37 hingga $78 \mathrm{~W} / \mathrm{m}^{2}$. Nilai fluks bahang terasa tahun 2000 berkisar antara 31 hingga $534 \mathrm{~W} /$ $\mathrm{m}^{2}$, sedangkan untuk tahun 2003 berkisar antara 50 hingga $508 \mathrm{~W} / \mathrm{m}^{2}$. Nilai fluks bahang laten tahun 2000 berkisar antara 65 hingga $670 \mathrm{~W} / \mathrm{m}^{2}$, sedangkan untuk tahun 2003 berkisar antara 60 hingga $645 \mathrm{~W} / \mathrm{m}^{2}$. Suhu udara tahun 2000 berkisar antara $0^{\circ}$ hingga $52^{\circ} \mathrm{C}$, sedangkan untuk tahun 2003 berkisar antara $1^{\circ}$ hingga $41^{\circ} \mathrm{C}$.
\end{abstract}

Kata Kunci : fluks bahang, suhu permukaan, radiasi netto, suhu udara, Landsat-8

\begin{abstract}
This study aimed to compare the value of air temperature in 2000, 2003 and 2013, as well as comparing the value of the net radiation, heat flux, and the air temperature in 2000 and 2003 in the area of path / row 118/065 is the northern part of East Java and Madura Island. The method used for the processing of surface temperature data is based on the value of radiance at band 6 of Landsat 7 ETM + path / row 118/065 2000 and 2003 as well as the value of radiance at band 10 and band 11 Landsat 8 TIRS path / row 118/065 2013. Net radiation between 2000 and 2003 using radiance and reflectance processing of Landsat 7 via the Stefan-Boltzmann equation approach. Soil heat flux using a radiance which is classified based on the value of the proportion of net radiation and soil heat in previous studies. Heat flux was using the Bowen ratio approach, while the latent heat flux using the energy balance equation. Temperatures predicted by the heat flux was combined with the aerodynamic resistance value. Value of air temperature in 2000 has a high value ranged from $8^{\circ}$ to $60^{\circ} \mathrm{C}$, while in 2003 ranged from $8^{\circ}$ to $45^{\circ} \mathrm{C}$ and 2013 ranged from $12.8^{\circ}$ to $41.2^{\circ} \mathrm{C}$. Net radiation in the study area in 2000 ranged from 366 to $792 \mathrm{~W} / \mathrm{m}^{2}$. While in 2003 ranged from 340 to $761 \mathrm{~W} / \mathrm{m}^{2}$. Soil heat flux values in 2000 ranged from 25 to $82 \mathrm{~W} / \mathrm{m}^{2}$, while the heat flux value of 2003 soil ranged from 37 to $78 \mathrm{~W} / \mathrm{m}^{2}$. Heat flux value was in 2000 ranged from 31 to $534 \mathrm{~W} / \mathrm{m}^{2}$, while for 2003 ranged from 50 to $508 \mathrm{~W} / \mathrm{m}^{2}$. Latent heat flux values in 2000 ranged from 65 to $670 \mathrm{~W} / \mathrm{m}^{2}$, while for 2003 ranged from 60 to $645 \mathrm{~W} / \mathrm{m}^{2}$. Temperatures in 2000 ranged from $0^{\circ}$ to $52^{\circ} \mathrm{C}$, while for 2003 ranged from $1^{\circ}$ to $41^{\circ} \mathrm{C}$.
\end{abstract}

Keywords: Surface temperature, net radiation, heat flux, air temperature, Landsat

\footnotetext{
${ }^{1}$ Pusat Pemanfaatan Penginderaan Jauh-LAPAN, Jalan Kalisari 8 Jakarta Timur. Telp: 021-8706582, Fax: 021-8722733

Email: wiweka@lapan.go.id
} 


\section{PENDAHULUAN}

Teknologi penginderaan jauh semakin berkembang melalui kehadiran berbagai sistem satelit dengan berbagai misi dan teknologi sensor. Aplikasi satelit penginderaan jauh telah mampu memberikan data/informasi tentang sumberdaya alam dataran dan sumberdaya alam kelautan secara teratur dan periodik. Ketersediaan data penginderaan jauh/citra satelit dalam bentuk digital memungkinkan penganalisaan dengan komputer secara kuantitatif dan konsisten. Selain itu data penginderaan jauh dapat digunakan sebagai input yang independen untuk verifikasi lapangan [1]. Dengan teknologi penginderaan jauh, penjelajahan lapangan dapat dikurangi, sehingga akan menghemat waktu dan biaya bila dibanding dengan cara turun langsung di lapangan. Salah satu analisis penginderaan jauh yang biasa digunakan adalah menggunakan citra satelit Landsat. Satelit Landsat bertujuan untuk menghasilkan data seri seluruh daratan dan wilayah pesisir bumi dengan perekaman citra menggunakan panjang gelombang tampak (visible) dan inframerah kualitas tinggi [2]. Neraca energi merupakan kesetimbangan antara masukan energi dari surya dengan kehilangan energi oleh permukaan setelah melalui proses-proses yang kompleks. Fluktuasi suhu udara berkaitan erat dengan proses pertukaran energi yang berlangsung di atmosfer. Pada siang hari, sebagian dari radiasi matahari akan diserap oleh gas -gas atmosfer dan partikel-partikel padat yang melayang di atmosfer. Serapan energi radiasi matahari akan menyebabkan suhu udara meningkat. Suhu udara harian maksimum tercapai beberapa saat setelah intensitas cahaya maksimum tercapai. Intensitas cahaya maksimum tercapai pada saat berkas cahaya jatuh tegak lurus, yakni pada waktu tengah hari.

Suhu permukaan mengindikasikan besarnya tutupan lahan pada wilayah tersebut, yang berpengaruh juga terhadap radiasi netto yang diserap dan dipantulkan oleh tutupan lahan. Selain hal itu, fluks bahang mengindikasikan besar energi yang diserap oleh sebuah tutupan lahan, dan mengindikasikan besarnya energi yang dibutuhkan untuk memanaskan permukaan [3]. Suhu udara pun akan dipengaruhi oleh jenis tutupan lahan yang berada di permukaan bumi. Perubahan atau alih fungsi lahan vegetasi menjadi lahan terbangun mengindikasikan adanya perubahan dari semua aspek yang telah dijelaskan, Sehingga dari hal-hal tersebut, dibutuhkan penelitian untuk melihat perubahan-perubahan nilai suhu permukaan, radiasi netto, fluks bahang, dan suhu udara.Penelitian ini akan melihat perubahan nilai suhu permukaan, radiasi netto, fluks bahang, dan suhu udara pada wilayah path/row 118/065 berdasarkan data citra satelit landsat $7 \mathrm{ETM}+$ tahun 2000 dan 2003 serta data citra satelit landsat 8 OLI/ TIRS tahun 2013. Tujuan penelitian ini adalah; 1) melihat dan membandingkan perubahan nilai suhu permukaan pada wilayah path/ row 118/065 tahun 2000, 2003, dan 2013; 2) melihat dan membandingkan perubahan radiasi netto, fluks bahang, dan suhu udara pada wilayah path/row 118/065 tahun 2000 dan 2003, dan; 3 ) membandingkan hasil nilai permukaan, radiasi netto, fluks bahang, dan suhu udara pada masing-masing tutupan lahan berupa badan air, vegetasi, awan, dan lahan terbangun.

Penginderaan jauh (inderaja) secara umum didefinisikan sebagai cara untuk memperoleh 
informasi dari obyek tanpa mengadakan kontak fisik dengan obyek tersebut, sedangkan secara khusus adalah usaha untuk mendeteksi gelombang elektromagnetik baik yang dipancarkan atau dipantulkan oleh obyek. Landsat 8 merupakan citra satelit Landsat yang terbaru, merupakan hasil dari USGS EROS Center. Landsat 8 menggunakan perhitungan dan kalibrasi skala Digital Number (DN) yang merepresentasikan gambar multispectral menggunakan dua hal yaitu Operational Land Imager (OLI) dan Thermal Infrared Sensor (TIRS). Produk landsat 8 menggunakan format data 16-bit unsigned integer yang dapat dirubah menjadi radiance dan reflectance Top Of Atmosphere (TOA). Suhu permukaan dapat diartikan suhu bagian terluar dari suatu obyek. Untuk suatu tanah terbuka, suhu permukaan adalah suhu pada lapisan terluar permukaan tanah sedangkan untuk vegetasi seperti hutan [4] dapat dipandang suhu permukaan kanopi tumbuhan dan pada tubuh air merupakan suhu dari permukaan air tersebut. Pada saat permukaan suatu benda menyerap radiasi, suhu permukaannya akan meningkat. Hal ini juga akan meningkatkan fluks energi (radiasi gelombang panjang) yang keluar dari permukaan benda tersebut. Suhu permukaan bukanlah suhu udara, keduanya memiliki nilai aktual yang bervariasi menurut ruang dan waktu. Suhu permukaan berpengaruh terhadap fluks bahang terasa (sensible heat), terutama pada siang hari, karena suhu permukaan benda lebih tinggi dibandingkan dengan suhu udara [5].

Pada saat permukaan suatu benda menyerap radiasi, suhu permukaannya belum tentu sama. Hal ini tergantung pada sifat fisik obyek pada permukaan tersebut. Sifat fisis obyek tersebut diantaranya: emisivitas, konduktivitas termal dan kapasitas panas jenis. Suatu obyek permukaan yang memiliki emisivitas dan kapasitas panas jenis rendah sedangkan konduktivitasnya termalnya tinggi akan menyebabkan suhu permukaan meningkat. Hal sebaliknya terjadi pada suatu obyek yang memiliki emisivitas dan kapasitas jenis yang tinggi sedangkan konduktivitas termalnya rendah akan menyebabkan lebih rendahnya suhu permukaan. Suhu permukaan akan mempengaruhi jumlah energi untuk memindahkan panas dari permukaan ke udara [6]. Radiasi gelombang pendek dan albedo diestimasi berdasarkan nilai spectral radiance yang diperoleh dari nilai digital number. Pada satelit penginderaan jauh, radiasi gelombang elektromagnetik yang dideteksi oleh sensor termal disebut "suhu kecerahan (Brightness Temperature)" [9,10]. Untuk menghitung nilai suhu permukaan pada data satelit Landsat sebelumnya harus diketahui dulu nilai suhu kecerahan. Estimasi suhu permukaan dari data thermal, nilai digital piksel citra harus dikonversi terlebih dahulu ke radiance menggunakan data kalibrasi sensor.

Radiasi netto adalah jumlah energi radiasi gelombang pendek yang datang dikurangi dengan energi radiasi gelombang pendek yang keluar ditambah energi radiasi gelombang panjang yang datang dan dikurangi energi gelombang panjang yang keluar. Berdasarkan persamaan radiasi netto, radiasi gelombang pendek ditentukan oleh nilai albedo, sedangkan radiasi gelombang panjang yang diterima bumi ditentukan oleh nilai suhu udara dan radiasi gelombang panjang yang keluar ditentukan oleh nilai suhu permukaan. Fluks bahang tanah (G) merupakan sejumlah energi matahari yang sampai pada permukaan 
tanah dan digunakan untuk berbagai proses fisik dan biologi tanah. Bentuk aliran energi pada fluks panas udara berupa konduksi di mana sebagian energi kinetik molekul benda/medium yang bersuhu lebih tinggi dipindahkan ke molekul benda yang lebih rendah melalui tumbukan molekul-molekul tersebut. Fluks bahang terasa $(\mathrm{H})$ atau fluks pemanasan udara merupakan energi yang digunakan untuk memindahkan panas dari permukaan ke udara. Fluks lengas terasa pada umumnya berlangsung secara konveksi dimana panas dipindahkan bersama-sama dengan fluida yang bergerak. Fluks bahang laten (LE) merupakan limpahan energi yang digunakan untuk menguapkan air ke atmosfer. Fluks panas laten adalah jumlah energi yang diperlukan untuk mengubah satu unit massa air menjadi uap pada suhu yang sama. Bila terjadi evaporasi, maka sistem yang berevaporasi mengalami pengurangan energi, sedangkan aliran energi akan bersifat positif. Pada proses ini terjadi konversi panas laten menjadi lengas terasa yang kemudian meningkatkan suhu udara dan menurunkan suhu permukaaan.Suhu permukaan bukanlah suhu udara. Nilai aktual keduanya bisa jauh berbeda dan bervariasi menurut ruang dan waktu. Suhu permukaan berpengaruh terhadap fluks bahang terasa
(Sensible heat), terutama pada siang hari, karena suhu permukaan benda lebih tinggi dari suhu udara. Suhu udara akan berfluktuasi dengan nyata selama setiap periode 24 jam. Fluktuasi suhu udara berkaitan erat dengan proses pertukaran energi yang berlangsung di atmosfer. Pada siang hari, sebagian dari radiasi matahari akan diserap oleh gas-gas atmosfer dan partikel-partikel padat yang melayang di atmosfer. Serapan energi radiasi matahari akan menyebabkan suhu udara meningkat. Suhu udara harian maksimum tercapai beberapa saat setelah intensitas cahaya maksimum tercapai. Intensitas cahaya maksimum tercapai pada saat berkas cahaya jatuh tegak lurus, yakni pada waktu tengah hari. Salah satu metode untuk menduga nilai suhu udara adalah dengan menggunakan metode regresi linear berganda dengan input berupa suhu permukaan, NDVI, ketinggian, serta letak lintang [7].

\section{METODOLOGI}

Bahan yang digunakan adalah data citra Landsat 7 ETM+ Path/Row 118/065 tahun 2000 dan 2003 serta citra Landsat 8 OLI/TIRS Path/Row 118/065 tahun 2013. Langkah yang dilakukan dalam mengerjakan penelitian ini disajikan dalam gambar 1 .

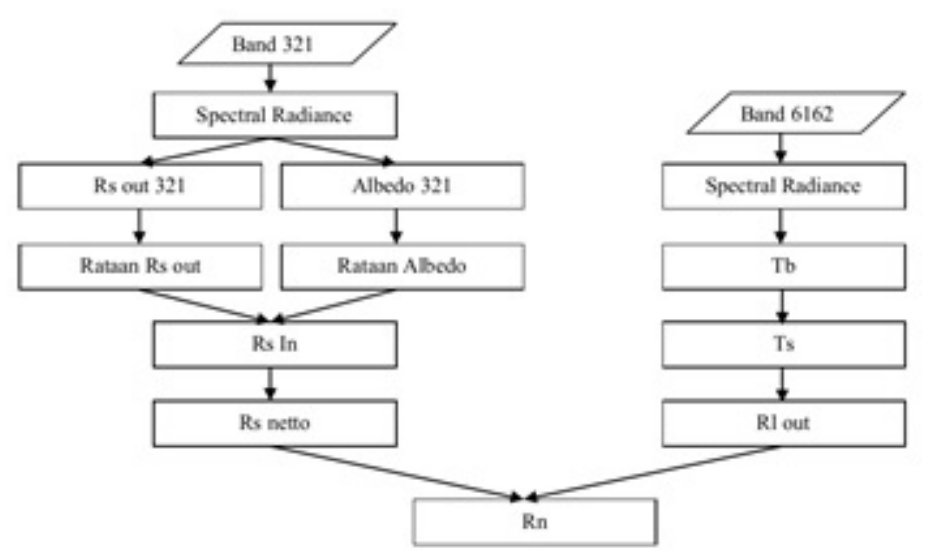

Gambar 1. Bagan Alir Penentuan Suhu Permukaan Dan Radiasi Netto 
Untuk menghitung suhu permukaan(Ts), dilakukan perhitungan spectral radiance $(\mathrm{L} \lambda)$ dan temperature brightness $\left(\mathrm{T}_{\mathrm{b}}\right)$, formulanya di persamaan (1), (2), dan (3). Bila digunakan citra satelit Landsat 7 ETM+ digunakan band 61 dan band 62

\section{a. Spectral radiance}

$\mathrm{L} \lambda=\left(\frac{\operatorname{Lmax} \lambda-\operatorname{Lmin} \lambda}{Q \operatorname{CAL\operatorname {max}}-Q \operatorname{QCAL\operatorname {min}}}\right) x(Q C A L-Q C A L \min )+\operatorname{Lmin} \lambda(1)$

Keterangan $: \mathrm{L}_{\lambda}=$ Spectral radiance pada kanal ke-i $\left(\mathrm{Wm}^{-2} \mathrm{sr}^{-1} \mu \mathrm{m}^{-1}\right), Q C A L=$ Nilai digital number kanal ke-i,$L_{\min }=$ Nilai minimum spectral radiance kanal ke-i, $L_{\max }=$ Nilai maksimum spectral radiance kanal ke-i, $Q C A L_{\min }=$ Minimum pixel value (1), $Q C A L_{\max }=$ Maksimum pixel value (255)

b. Temperature Brightness (Tb)

$$
\mathrm{Tb}=\frac{K 2}{\ln \left(\frac{K 1}{L \lambda}+1\right)}
$$

Keterangan $: \mathrm{Tb}=$ Temperature Brightness (K), $\mathrm{K} 1=666.09\left(\mathrm{Wm}^{-2} \mathrm{sr}^{-1} \mu \mathrm{m}^{-}\right.$ $\left.{ }^{1}\right), \mathrm{K} 2=1282.71(\mathrm{~K}), \mathrm{L}_{\lambda}=$ Spectral radiancepadakanalke-i $\left(\mathrm{Wm}^{-2} \mathrm{sr}^{-1} \mu \mathrm{m}^{-1}\right)$

c. Suhu permukaan (Ts)

$$
\mathrm{Ts}=\frac{T b}{1+\left(\frac{\lambda T b}{\delta}\right) \ln \varepsilon}
$$

Keterangan $: \mathrm{Ts}=$ permukaan $(\mathrm{K}), \mathrm{Tb}=-$ Temperature Brightness (K), $\lambda=11.5 \mu \mathrm{m}$ (Nilai tengah panjang gelombang kanal $6, \delta=$ hc/ $\sigma$ besarnya $\left(1.438 \times 10^{-2} \mathrm{~m}\right.$ $\mathrm{K}), \mathrm{h}=$ Konstanta Planck (6.26 x 10 $0^{-34} \mathrm{~J}$ $\mathrm{sec}), \mathrm{c}=$ Kecepatancahaya $(2.998 \mathrm{x}$ $\left.10^{8} \mathrm{~m} \mathrm{~s}^{-1}\right), \sigma=$ Konstanta Stefan-Boltzman $\left(1.38 \times 10^{-23} \mathrm{~J} \mathrm{~K}^{-1}\right), \varepsilon=$ Emisivitasobjek, untukbadan air $=0.98, \mathrm{RTH}=0.95$, non$\mathrm{RTH}=0.92$
Untuk menghitung radiasi netto $(\mathrm{Rn})$, digunakan spectral radiance $(\mathrm{L} \lambda)$, radiasi gelombang pendek keluar (Rs Out), albedo $(\alpha)$, radiasi gelombang pendek masuk (Rs In), radiasi gelombang pendek netto (Rs Netto), radiasi gelombang panjang keluar (Rl Out)

a. Spectral radiance

$\mathrm{L} \lambda=\left(\frac{\operatorname{Lmax} \lambda-\operatorname{Lmin} \lambda}{Q C A L \max -Q C A L \min }\right) x(Q C A L-Q C A L \min )+\operatorname{Lmin} \lambda(4)$

Keterangan : $\mathrm{L}_{\lambda}=$ Spectral radiance pada kanal ke-i $\left(\mathrm{Wm}^{-2} \mathrm{sr}^{-1} \mu \mathrm{m}^{-1}\right)$, QCAL

$=$ Nilai digital number kanal ke-i, $\mathrm{L}_{\text {min }}$ $=$ Nilai minimum spectral radiance kanal ke-i, $\mathrm{L}_{\max }=$ Nilai maksimum spectral radiance kanal ke-i, $\mathrm{QCAL}_{\min }=$ Minimum pixel value (1), $\mathrm{QCAL}_{\text {max }}$ $=$ Maksimum pixel value (255)

b. Radiasi gelombang pendek keluar (Rs Out)

$$
\text { Rs Out }=\pi \times \operatorname{L} \lambda \times \mathrm{d}^{2} \times \frac{1}{\text { Band }}
$$

Keterangan:Rs Out $=$ Radiasi Gelombang Pendek Keluar $\left(\mathrm{W} / \mathrm{m}^{2}\right), \mathrm{d}^{2}=$ Jarak astronomi matahari ke bumi (dalam unit astronomi), $\mathrm{L}_{\lambda} \quad=$ Spectral radiance pada kanal ke-i $\left(\mathrm{Wm}^{-2} \mathrm{sr}^{-1} \mu \mathrm{m}^{-1}\right), \quad \frac{1}{\text { Band }}$ $=$ Nilai tengah dari panjang gelombang tiap band (Tabel 1)

\section{Tabel 1. Nilai Tengah Dari Panjang Gelombang Tiap Band}

\begin{tabular}{c|c}
\hline $\begin{array}{c}\text { Spektral } \\
\text { Band }\end{array}$ & Half-Amplitude Bandwidth \\
\hline 1 & $0.450-0.515$ \\
2 & $0.525-0.605$ \\
3 & $0.630-0.690$ \\
4 & $0.775-0.900$ \\
5 & $1.550-1.750$ \\
6 & $10.40-12.50$ \\
7 & $2.090-2.350$ \\
\hline
\end{tabular}


c. Albedo $(\alpha)$

$\alpha=\frac{\pi \cdot \mathrm{L}_{\lambda} \cdot \mathrm{d}^{2}}{\operatorname{ESUN} \mathrm{N}_{\lambda} \cdot \cos \theta}$

Keterangan : $\mathrm{ESUN}=$ Rata-rata nilai solar spectral IrradianceETM+ Solar Spectral Irradiances (Tabel 2), $\mathrm{L}_{\lambda}=\mathrm{S}$ pectra 1 radiance padakanalke-i $\left(\mathrm{Wm}^{-2} \mathrm{sr}^{-1} \mu \mathrm{m}^{-1}\right)$, $\theta \mathrm{s}=$ Sudut zenit matahari $\left(90^{\circ}-\right.$ sun elevation), $\mathrm{d}^{2}=$ Jarak astronomi matahari ke bumi (dalam unit astronomi), $\pi=$

Tabel 2. Band landsatETM+ Solar Spectral Irradiances

\begin{tabular}{c|c}
\hline Band & watt $/ \mathbf{m}^{2} \boldsymbol{\mu m}$ \\
\hline 1 & 1997 \\
2 & 1812 \\
3 & 1533 \\
4 & 1039 \\
5 & 230,8 \\
7 & 84,9 \\
8 & 1362 \\
\hline
\end{tabular}

d. Radiasi gelombang pendek masuk (Rs In) $\alpha=\frac{R s O u t}{R \sin }$ maka Rs In $=\frac{R s \text { out }}{\alpha}(7)$

Keterangan: Rs In= Radiasi gelombang pendek masuk $\left(\mathrm{W} / \mathrm{m}^{2}\right)$, Rs Out=Radiasi gelombang pendek keluar $\left(\mathrm{W} / \mathrm{m}^{2}\right), \alpha$ = Albedo e. Radiasi gelombang pendek netto (Rs Netto)

$$
\mathrm{Rs}_{\text {netto }}=\mathrm{RS}_{\text {In }}-\mathrm{Rs}_{\mathrm{SOu}}
$$

Keterangan: $\mathrm{Rs}_{\text {netto }}=$ Radiasi gelombang pendek netto $\left(\mathrm{W} / \mathrm{m}^{2}\right)$, Rs $\mathrm{In}=$ Radiasi gelombang pendek masuk $\left(\mathrm{W} / \mathrm{m}^{2}\right)$, Rs Out $=$ Radiasi gelombang pendek keluar $\left(\mathrm{W} / \mathrm{m}^{2}\right)$

f. Radiasi gelombang panjang keluar (R1 Out)

$$
\text { Rl Out }=\bar{\varepsilon} \bar{\sigma} \mathrm{Ts}^{4}
$$

Keterangan:Rs Out $=\mathrm{Radiasi}$ gelombang panjang keluar $\left(\mathrm{W} / \mathrm{m}^{2}\right), \varepsilon$

= Emisivitas objek, untuk badan air= $0.98, \mathrm{RTH}=0.95$, non-RTH $=0.92, \sigma$

= Tetapan Stefan-Boltzman (5.67 x 10-

$\left.{ }^{8} \mathrm{Wm}^{2} \mathrm{~K}^{-4}\right)$, Ts $=$ Suhu permukaan $(\mathrm{K})$

g. Radiasi netto (Rn)

$\mathrm{Rn}=\mathrm{Rs}_{\text {netto }}-\mathrm{R} \mathrm{l}_{\text {Out }}$

Keterangan:Rs ${ }_{\text {netto }}=\mathrm{R}$ adiasi gelombang pendek netto $\left(\mathrm{W} / \mathrm{m}^{2}\right), \mathrm{Rs}_{\text {Out }}$ $=$ Radiasi gelombang panjang keluar $(\mathrm{W} /$ $\mathrm{m}^{2}$ )

Untuk menghitungfluks bahang dan suhu udaramenggunakan data pengolahanRn, Ts,danreclass band 542 .

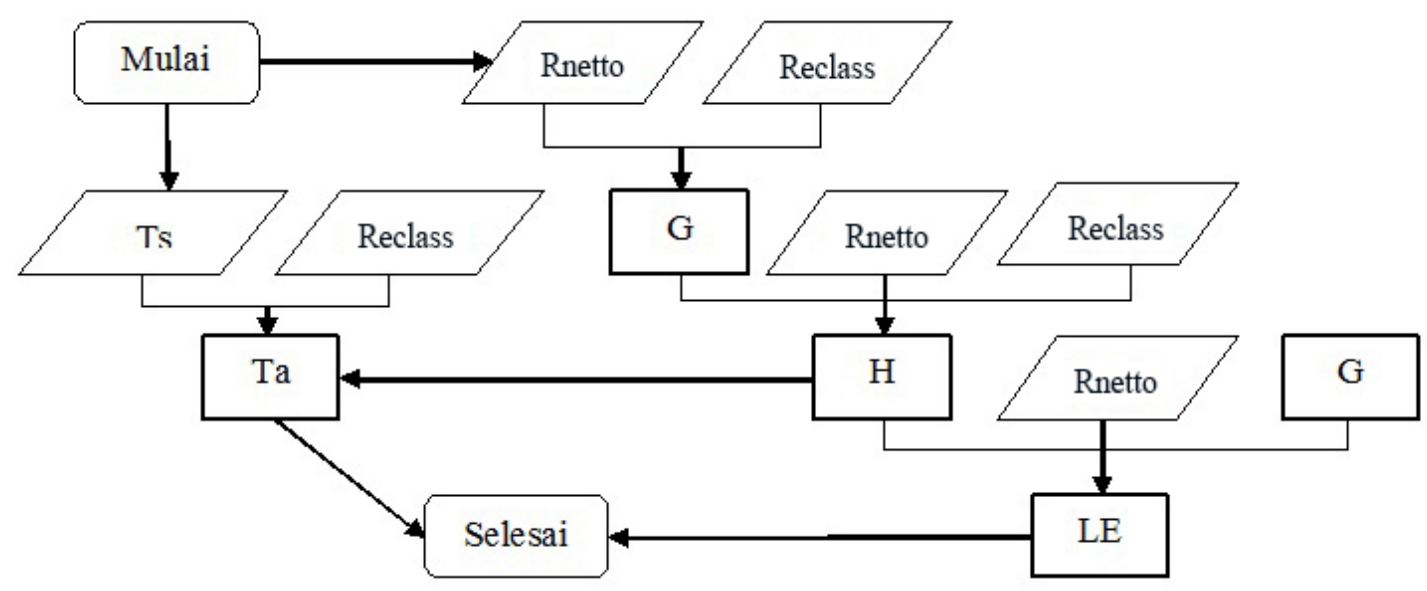

Gambar 2. Bagan alir penentuan fluks bahang dan suhu udara 
a. Fluks bahang tanah $(\mathrm{G})$

$\frac{G}{R n}=\frac{T s}{\alpha}\left(0.0038 \alpha+0.0074 \alpha^{2}\right)\left(1-0.98 N D V I^{4}\right)$

Keterangan: $\mathrm{G}=$ Perpindahan panas tanah (soil heat flux) $\left(\mathrm{Wm}^{-2}\right), \mathrm{Rn}=$ Radiasi netto $\left(\mathrm{Wm}^{-2}\right)$

$\alpha=$ Albedo permukaan, NDVI= Normalized Difference Vegetation Index, $\mathrm{Ts}=$ Suhu permukaan $(\mathrm{K}), \mathrm{G}=$ Proporsi * $\mathrm{Rn}$

Tabel 3. Nilai Rn, G Dan Proporsi Untuk TiapTiap Kelas Penutup Lahan

\begin{tabular}{cccc}
\hline PenutupanLahan & Rn & G & Proporsi \\
\hline Tambak & 212 & 15 & 0.07 \\
SawahVegetasi & 208 & 17 & 0.08 \\
SawahBera & 195 & 20 & 0.1 \\
Industri & 194 & 21 & 0.11 \\
Perkotaan & 194 & 20 & 0.1 \\
Perdesaan & 201 & 19 & 0.1 \\
Belukar & 207 & 18 & 0.09 \\
Perkebunan & 213 & 16 & 0.08 \\
\hline
\end{tabular}

b. Fluks bahang terasa $(\mathrm{H})$

$\mathrm{H}=\frac{\beta\left(R_{n}-G\right)}{1+\beta}$

Keterangan:H=Perpindahan panas terasa (sensible heat flux) $\left(\mathrm{Wm}^{-2}\right), \mathrm{Rn}=$ Radiasi netto $\left(\mathrm{Wm}^{-2}\right), \beta=$ Bowen Ratio, $\mathrm{G}$

$=$ Perpindahanpanastanah, soil heat flux $\left(\mathrm{Wm}^{-2}\right), \beta=$

\section{Tabel4. Nilai Bowen Ratio UntukTiap Tiap KelasP enutup Lahan}

\begin{tabular}{cc}
\hline PenutupanLahan & Bowen Ratio ( $\boldsymbol{\beta})$ \\
\hline Pemukiman & 4.0 \\
Perkebunan & 0.5 \\
Air & 0.11 \\
Sawah & 0.25 \\
HutanTropis & 0.33 \\
\hline
\end{tabular}

c. Fluks bahang laten (LE)

$\mathrm{Rn}-\mathrm{G}-\mathrm{H}=\overline{\mathrm{LE}}$

Keterangan: $\mathrm{H}=$ Perpindahan panas terasa (sensible heat flux) $\left(\mathrm{Wm}^{-2}\right), \mathrm{G}=$ Perpindahan panas tanah (soil heat flux) $\left(\mathrm{Wm}^{-2}\right), \mathrm{Rn}=$ Radiasi netto $\left(\mathrm{Wm}^{-2}\right)$

d. Suhu udara (Ta)

$$
\mathrm{Ta}=\mathrm{Ts}-\left(\frac{H r_{a H}}{\rho_{\text {air }} c_{p}}\right)
$$

Keterangan: $\mathrm{H}=$ Fluks Pemanasan Udara (Wm -2), pair= Kerapatan udara lembab $\left(1,27 \mathrm{Kg} \mathrm{m}^{-3}\right), \mathrm{Cp}=$ Panas spesifik udara pada tekanan konstan $\left(1004 \mathrm{JKg}^{-1} \mathrm{~K}^{-}\right.$ $\left.{ }^{1}\right), T s=$ Suhu permukaan $(\mathrm{K}) \mathrm{Ta}=\mathrm{Suhu}$ udara $(\mathrm{K}), \mathrm{raH}=$ Tahanan aerodinamik $\left(\mathrm{sm}^{-1}\right), \mathrm{raH}=31.9 \mathrm{u}^{-0.96}$

Tabel 5. Nilai Kecepatan Angin Untuk TiapTiap Kelas Penutup Lahan

\begin{tabular}{cc}
\hline PenutupanLahan & KecepatanAngin $\left(\mathbf{m s}^{-1}\right)$ \\
\hline Air & 2.01 \\
Non vegetasi & 1.79 \\
Vegetasi & 1.41 \\
\hline
\end{tabular}

\section{HASIL DAN PEMBAHASAN}

Radiasi gelombang pendek dan albedo diestimasi berdasarkan nilai spectral radiance yang diperoleh dari nilai digital number. Pada satelit penginderaan jauh, radiasi gelombang elektromagnetik yang dideteksi oleh sensor termal disebut "suhu kecerahan (Brightness Temperature)". Untuk menghitung nilai suhu permukaan pada data satelit Landsat sebelumnya harus diketahui dulu nilai suhu kecerahan. Estimasi suhu permukaan dari data thermal, nilai digital piksel citra harus dikonversi terlebih dahulu ke radiance 
menggunakan data kalibrasi sensor. Suhu permukaan di wilayah Kajian pada tahun 2000 berkisar antara $8^{\circ}$ hingga $60{ }^{\circ} \mathrm{C}$ tersaji di gambar 3. Sedangkan pada tahun 2003 nilai suhu permukaan berkisar antara $8^{\circ}$ hingga $45{ }^{\circ} \mathrm{C}$ tersaji di gambar 4 . Suhu permukaan bernilai rendah terdapat pada awan dan dataran tinggi (gunung atau bukit), dimana awan dan dataran tingi memiliki suhu yang lebih rendah dibandingkan semua tutupan lahan dan ketinggian yang ada dipermukaan. Untuk suhu permukaan yang bernilai tinggi, terdapat di lahan terbangun, yang merupakan wilayah yang kurang ditutupi oleh vegetasi dan merupakan daerah dataran rendah.

Radiasi netto adalah jumlah energy radiasi gelombang pendek yang datang dikurangi dengan energy radiasi gelombang pendek yang keluar ditambah energy radiasi gelombang panjang yang datang dan dikurangi energy gelombang panjang yang keluar. Berdasarkan persamaan radiasi netto, radiasi gelombang pendek ditentukan oleh nilai albedo, sedangkan radiasi gelombang panjang yang diterima bumi ditentukan oleh nilai suhu udara dan radiasi gelombang panjang yang keluar ditentukan oleh nilai suhu permukaan. Radiasi netto di wilayah kajian pada tahun 2000 berkisar antara 366 hingga $792 \mathrm{~W} / \mathrm{m}^{2}$ tersaji di gambar 5. Sedangkan pada tahun 2003 berkisar antara 340 hingga $761 \mathrm{~W} / \mathrm{m}^{2}$ tersaji di gambar 6. Radiasi netto bernilai tinggi terdapat pada badan air dan daerah dataran tinggi, pada tempat ini nilai radiasi netto bernilai tinggi karena merupakan wilayah yang lebih banyak menyerap radiasi dan sedikit untuk mengembalikan radiasi tersebut, radiasinya berbentuk radiasi gelombang panjang dan pendek. Nilai radiasi netto bernilai kecil pada awan, dimana awan lebih banyak menyerap radiasi dibandingkan mengembalikan radiasi tersebut.Fluks bahang terdiri dari fluks bahang tanah $(\mathrm{G})$, fluks bahang terasa $(\mathrm{H})$, dan fluks bahang laten (LE). Fluks bahang tanah (G) merupakan sejumlah energi matahari yang sampai pada permukaan tanah dan digunakan untuk berbagai proses fisik dan biologi tanah. Bentuk aliran energi pada fluks panas udara berupa konduksi di mana sebagian energi kinetik molekul benda/medium yang bersuhu lebih tinggi dipindahkan ke molekul benda yang lebih rendah melalui tumbukan molekul-molekul tersebut.

Fluks bahang tanah pada wilayah kajian tahun 2000 dan tahun 2003 memiliki nilai tertinggi di wilayah darat tersaji di gambar 7 dan gambar

Tabel 5. Hasil Perhitungan Nilai-Nilai Suhu Permukaan, Radiasi Netto, Fluks Bahang Tanah, Fluks Bahang Terasa, Fluks Bahang Laten, Dan Suhu Udara

\begin{tabular}{cccc}
\hline & $\begin{array}{c}\text { Tahun } \\
\mathbf{2 0 0 0}\end{array}$ & Tahun 2003 & Tahun 2013 \\
& $8-60$ & $8-45$ & $12.8-42.1$ \\
SuhuPermukaan $\left({ }^{\circ} \mathrm{C}\right)$ & $366-792$ & $340-761$ & - \\
RadiasiNetto $\left(\mathrm{W} / \mathrm{m}^{2}\right)$ & $25-82$ & $37-78$ & - \\
FluksBahang Tanah $\left(\mathrm{W} / \mathrm{m}^{2}\right)$ & $31-534$ & $50-508$ & - \\
Fluks Bahang Terasa $\left(\mathrm{W} / \mathrm{m}^{2}\right)$ & $65-670$ & $60-645$ & - \\
FluksBahangLaten $\left(\mathrm{W} / \mathrm{m}^{2}\right)$ & $65-52$ & $1-41$ & - \\
SuhuUdara $\left({ }^{\circ} \mathrm{C}\right)$ & $0-52$ & & \\
\hline
\end{tabular}


8, karena fluks bahang tanah merupakan energi yang digunakan untuk memanaskan permukaan dengan cara konduksi, sehingga tanah merupakan media/objek yang paling terpengaruhi oleh fluks tersebut. Berbeda dengan air dan awan yang memiliki nilai fluks bahang tanah yang kecil karena air dan awan lebih banyak dipanaskan dalam proses konveksi. Nilai fluks bahang tanah tahun 2000 berkisar antara 25 hingga $82 \mathrm{~W} / \mathrm{m}^{2}$, sedangkan tahun 2003 nilai fluks bahang tanah berkisar antara 37 hingga $78 \mathrm{~W} / \mathrm{m}^{2}$.Fluks bahang terasa (H) atau fluks pemanasan udara merupakan energi yang digunakan untuk memindahkan panas dari permukaan ke udara. Fluks lengas terasa pada umumnya berlangsung secara konveksi dimana panas dipindahkan bersama-sama dengan fluida yang bergerak. Fluks bahang terasa pada wilayah kajian tahun 2000 dan 2003 memiliki nilai tertinggi di awan, hal tersebut terjadi karena awan terpanaskan melalui proses konveksi serta awan merupakan proses pengangkatan massaa fluida ke udara yang didorong oleh fluks bahang tersa tersebut. Nilai terkecil fluks bahang terasa terdapat di wilayah perairan, hal tersebut dikarenakan air memiliki kapasitas panas yang tinggi sehingga mampu menjaga panas dalam keadaan yang lebih lama yang menjadikan fluks bahang terasa itu kecil. Nilai fluks bahang terasa tahun 2000 berkisar antara 31 hingga $534 \mathrm{~W} / \mathrm{m}^{2}$, sedangkan untuk tahun 2003 berkisar antara 50 hingga $508 \mathrm{~W} /$ $\mathrm{m}^{2}$ tersaji di gambar 9 dan gambar 10. Fluks bahang laten (LE) merupakan limpahan energi yang digunakan untuk menguapkan air ke atmosfer. Menurut Monteith dan Unsworth (1990), fluks panas laten adalah jumlah energi yang diperlukan untuk mengubah satu unit massa air menjadi uap pada suhu yang sama. Bila terjadi evaporasi, maka sistem yang berevaporasi mengalami pengurangan energi, sedangkan aliran energi akan bersifat positif. Pada proses ini terjadi konversi panas laten menjadi lengas terasa yang kemudian meningkatkan suhu udara dan menurunkan suhu permukaaan. Fluks bahang terasa pada wilayah kajian tahun 2000 dan 2003 memiliki nilai tertinggi di badan air, hal tersebut karena membutuhkan energi yang besar untuk menguapkan air, sehingga fluks bahang laten tersebut bernilai tinggi. selain itu, air memiliki kapasitas panas yang tinggi sehingga dibutuhkan energi yang besar untuk mengubah bentuknya menjadi uap air. Nilai fluks bahang laten terkecil terdapat di daratan rendah yang cenderung kering dan memiliki sedikit kandungan air, sehingga energi yang diperlukan untuk mengupakan air tidak terlalu besar. Nilai fluks bahang laten tahun 2000 berkisar antara 65 hingga $670 \mathrm{~W} / \mathrm{m}^{2}$, sedangkan untuk tahun 2003 berkisar antara 60 hingga $645 \mathrm{~W} / \mathrm{m}^{2}$ terjsaji di gamabr 11 dan gambar 12. Suhu udara pada wilayah kajian tahun 2000 dan 2003 memiliki nilai tertinggi di wilayah lahan terbangun tersaji di gambar 13 dan gambar 14, hal tersebut karena pada lahan terbangun tidak terjadi penyerapan radiasi, sehingga lebih banyak memantulkan. Hal tersebut menyebabkan suhu udara meningkat, sesuai dengan fluks bahang terasa yang tinggi energinya di wilayah tersebut. Nilai suhu udara pada wilayah kajian tahun 2000 berkisar antara $0^{\circ}$ hingga $52^{\circ} \mathrm{C}$, sedangkan untuk tahun 2003 berkisar antara $1^{\circ}$ hingga $41^{\circ} \mathrm{C}$. Untuk tahun 2013, data yang digunakan adalah data citra landsat 8 OLI/TIRS. Pada tahun 2013 hanya menghitung nilai dari suhu permukaan 
berdasarkan reflectance yang di miliki oleh sensor thermal yaitu TIRS. Nilai reflectance pada landsat 8 dapat dilihat pata meta data citra satelit tersebut. Berdasarkan perhitungan reflectance tersebut, didaptkan nilai suhu permukaan pada tahun 2013 berkisar antara $12.8^{\circ}$ hingga $42.1^{\circ} \mathrm{C}$. Pada tahun 2013 nilai radiasi netto, fluks bahang dan suhu udara tidak dilakukan pengolahan, karena terdapat metode yang berbeda dan belum menemukan metode yang sesuai untuk mengolah nilai tersebut berdasarkan radiance dari citra landsat 8 tersebut.

\section{SIMPULAN}

Suhu udara dari tahun 2000, 2003, dan 2013 mengalami penurunan hal tersebut diakibatkan oleh banyaknya tutupan awan pada tahun 2003 dan 2013 sehingga mempengaruhi nilai dari suhu permukaan tersebut. Pada radiasi netto dan fluks bahang tahun 2000 dan 2003 terjadi perubahan yang terlalu signifikan, dapat diartikan bahwa untuk tahun 2000 dan 2003 tidak terjadi perubahan tutupan lahan

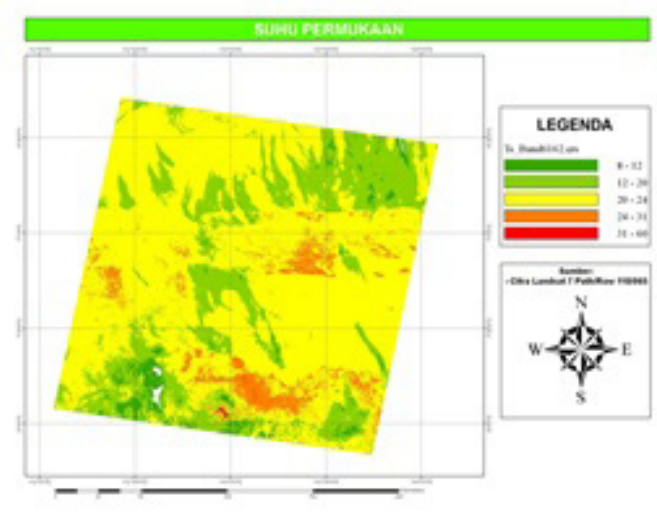

Gambar 3. Suhu permukaan tahun 2000 yang terlalu signifikan. Untuk suhu udara terjadi penurunan pada tahun 2000 ke tahun 2003, hal tersebut karena adanya tutupan awan yang menyebabkan suhu udara sekitar awan lebih dingin dari suhu permukaan bumi. Suhu permukaan memiliki nilai tertinggi pada penutupan lahan terbangun dan suhu permukaan terendah dimiliki oleh awan. Radiasi netto tertinggi terdapat pada badan air dan daerah dataran tinggi dan radiasi netto bernilai kecil pada awan. Fluks bahang memiliki nilai tertinggi di wilayah darat dan nilai fluks bahang tanah yang kecil terdapat pada air dan awan. Fluks bahang terasa memiliki nilai tertinggi di awan dan nilai terkecil fluks bahang terasa terdapat di wilayah perairan. Fluks bahang terasa memiliki nilai tertinggi di badan air dan nilai fluks bahang laten terkecil terdapat di daratan rendah. Suhu udara memiliki nilai tertinggi di wilayah lahan terbangun, hal tersebut karena pada lahan terbangun tidak terjadi penyerapan radiasi, sehingga lebih banyak memantulkan yang menyebabkan terjadi akumulasi bahang di udara.

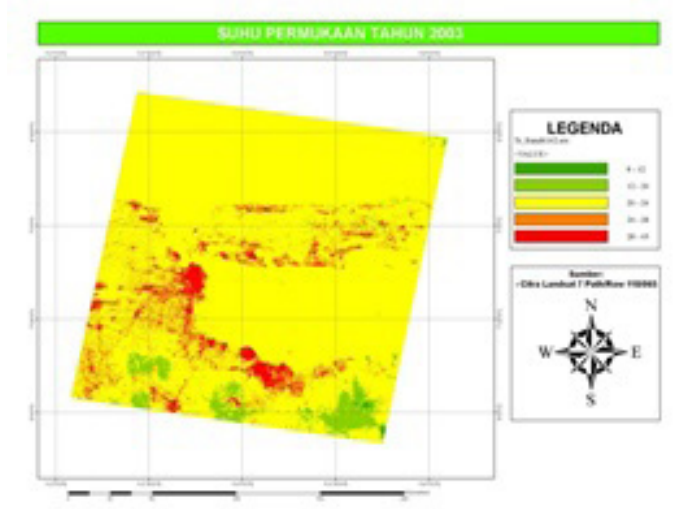

Gambar 4. Suhu permukaan tahun 2003 


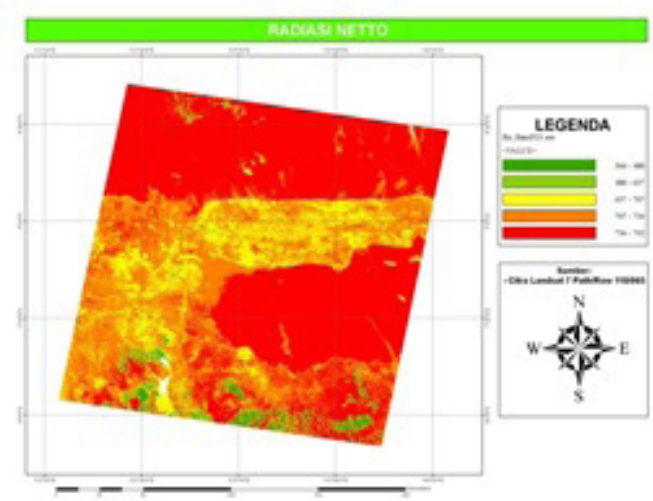

Gambar 5. Radiasi netto tahun 2000

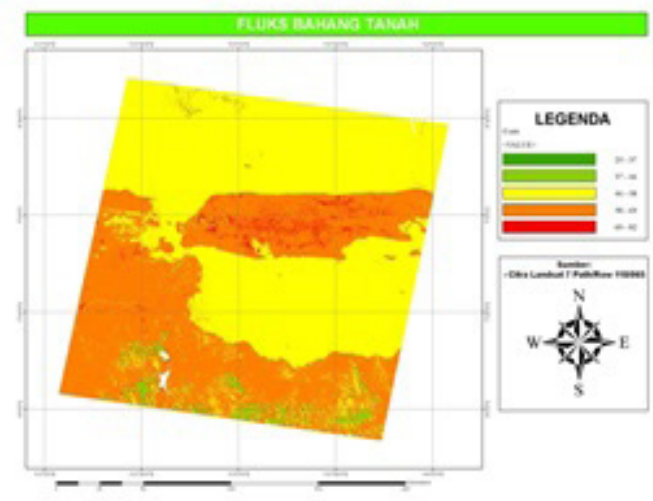

Gambar 7. Fluks bahang tanah tahun2000

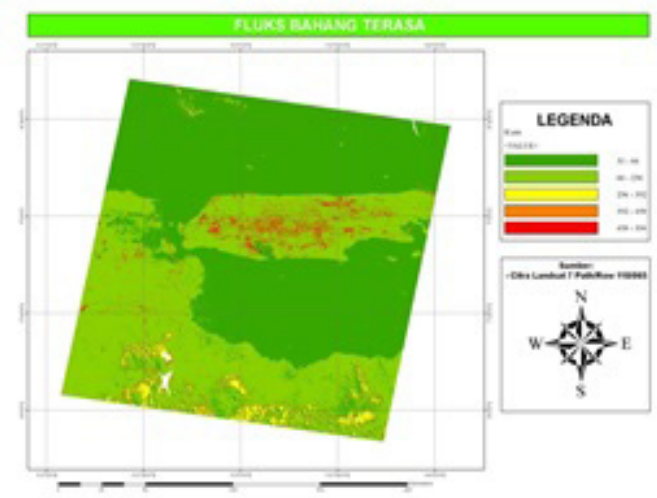

Gambar 9. Fluks bahang terasa tahun2000

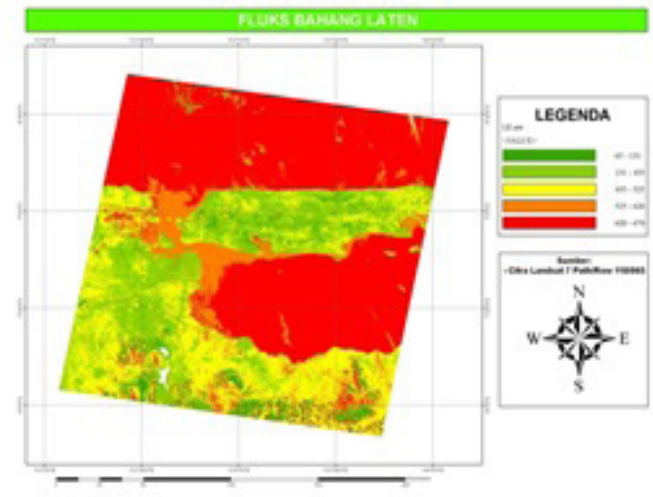

Gambar 11. Fluks bahang laten tahun2000

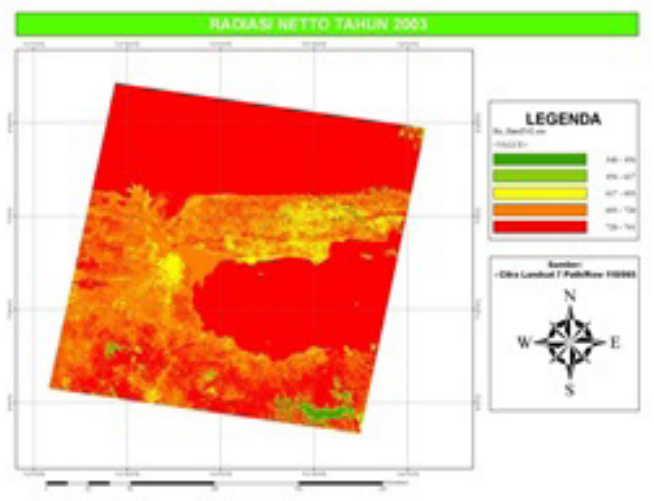

Gambar 6. Radiasi netto tahun 2003

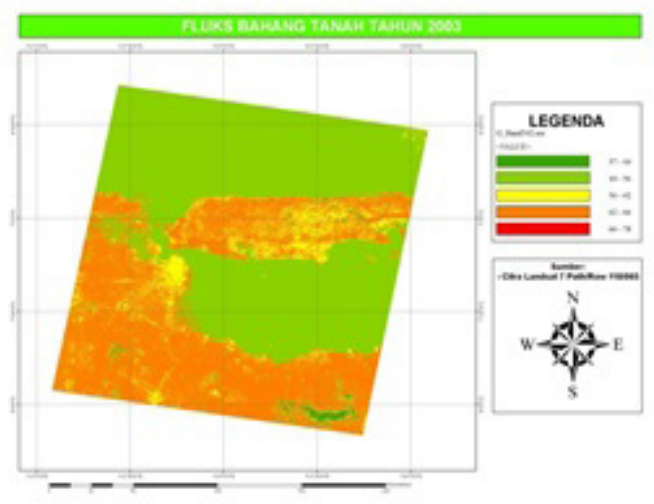

Gambar 8. Fluks bahang tanah tahun 2003

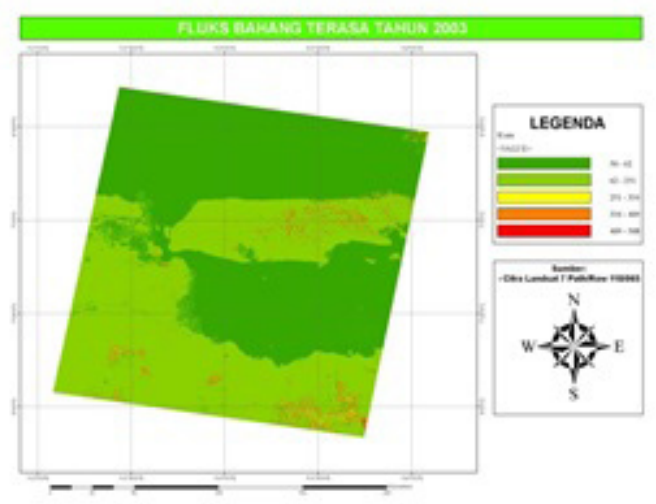

Gambar 10. Fluks bahang terasa tahun2003

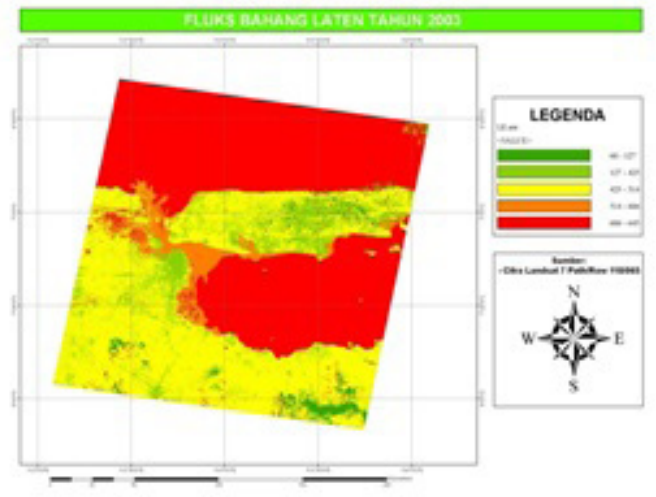

Gambar 12. Fluks bahang laten tahun2003 Gambar 12. Fluks bahang laten tahun2003 


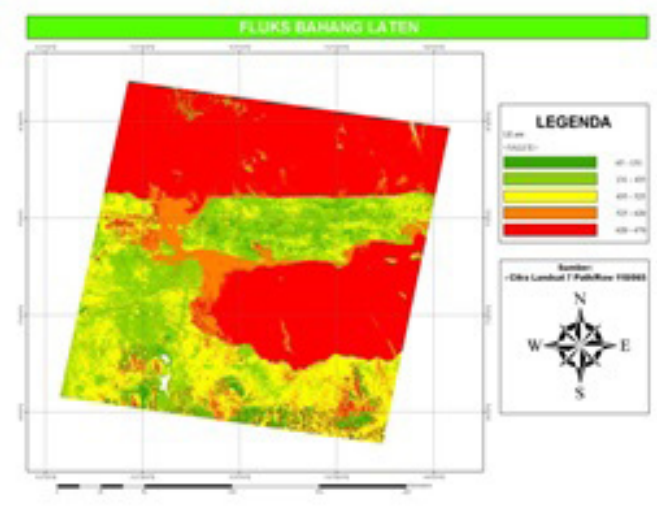

Gambar 13. Suhu udara tahun 200

\section{DAFTAR PUSTAKA}

(1) Rubini A. 1995. Land Resource Balance. Conference Proceeding on Remote Sensing and GIS for Environmental Resources Management, BPPT New Building, Jakarta, June 6-8, 1995: page 7-1 to 7-14. Agency for The Assessment and Application of Technology (BPPTeknologi), Jalan Thamrin No.8 Jakarta.

(2) Purwadhi F.S.H. 2001. Interpretasi Citra Digital. Jakarta: PT Grasindo.

(3) USGS. 2002. Landsat 7 Science Data Users Handbook. http://ltpwww.gsfc. nasa.gov/IAS/handbook_htmls/ chapter111.html. [14 April 2012]

(4) Handayani N. 2007. Identifikasi Perubahan Kapasitas Panas Kawasan Perkotaan Dengan Menggunakan Citra Landsat TM/ETM+ (studi kasus : Kodya Bogor). Skripsi. Bogor: Jurusan Geofisika dan Meteorologi FMIPA IPB.

(5) Kalfuadi Y. 2009. Analisis Temperature Heat Index (THI) Dalam Hubungannya Dengan Ruang Terbuka Hijau (studi kasus : Kabupaten Bungo - Propinsi Jambi). Skripsi. Bogor: Jurusan Geofisika dan meteorology FMIPA IPB.

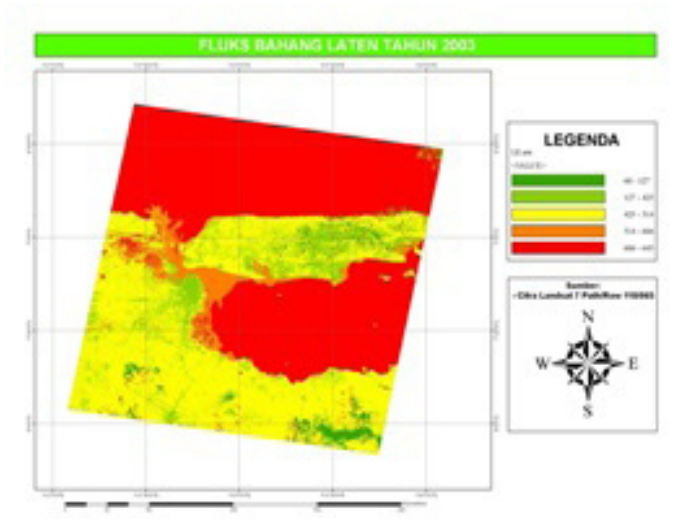

Gambar 14. Suhu udara tahun 2003bar 12. Fluks bahang laten tahun 2003

(6) Kiefer TM. Dan Lillesand RW. 1990. Penginderaan Jauh dan Interpretasi Citra. Yogyakarta: Gadjah Mada University Press. Bulaksumur.

(7) Khomarudin M R, Roswintiarti O, Tjahjaningsih A. 2005. Estimasi Unsur-Unsur Cuaca Untuk Mendukung Sistem Peringkat Bahaya Kebakaran Hutan/Lahan Dengan Data Modis. Jakarta: LAPAN

(8) Ligar BW. 2008. Penyusunan Metode Kuantifikasi Pengaruh Luas Dan Jarak RTH Terhadap Kondisi Suhu Udara Dengan Menggunakan Data Satelit. Skripsi. Bogor: Jurusan Geofisika dan Meteorologi FMIPA IPB.

(9) Offer Rozenstein 1, Zhihao Qin , Yevgeny Derimian and Arnon Karnieli ,Derivation of Land Surface Temperature for Landsat-8 TIRS Using a Split Window Algorithm, Sensors 2014, 14, 5768-5780; doi:10.3390/s140405768,ISSN 14248220, www.mdpi.com/journal/sensors

(10) Rajeshwari A, Mani N D2, Estimation Of Land Surface Temperature Of Dindigul District Using Landsat 8 Data, Ijret: International Journal Of Research In Engineering And Technology Eissn: 2319-1163 | Pissn: 2321-7308 